INTRODUCTORY ECONOMICS 


\section{INTRODUCTORY ECONOMICS}

Barry Harrison

Charles Smith

Brinley Davies

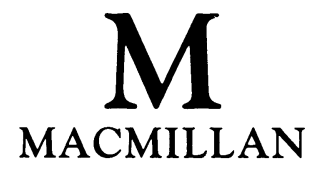


(C) Barry Harrison, Charles Smith and Brinley Davies 1992

All rights reserved. No reproduction, copy or transmission of this publication may be made without written permission.

No paragraph of this publication may be reproduced, copied or transmitted save with written permission or in accordance with the provisions of the Copyright, Designs and Patents Act 1988, or under the terms of any licence permitting limited copying issued by the Copyright Licensing Agency, 90 Tottenham Court Road, London W1P 9HE.

Any person who does any unauthorised act in relation to this publication may be liable to criminal prosecution and civil claims for damages.

First published 1992 by

THE MACMILLAN PRESS LTD

Houndmills, Basingstoke, Hampshire RG21 2XS

and London

Companies and representatives

throughout the world

ISBN 978-0-333-54294-1 ISBN 978-1-349-22006-9 (eBook)

DOI 10.1007/978-1-349-22006-9

A catalogue record for this book is available from the British Library

Copy-edited and typeset by Povey-Edmondson

Okehampton and Rochdale, England 


\section{CONTENTS}

List of Figures

List of Tables

Acknowledgements

Preface

1 WHAT IS ECONOMICS?

Connections

Key concepts

What is economics?

The ecomonic problem

Opportunity cost

Production possibility curves

Economic systems

Review questions

2 THE TOOLS OF ECONOMIC ANALYSIS

Connections

Key concepts

Economics as a social science

The presentation of economic data

The sources of economic data

Economic data and economic policy

Review questions

\section{DEMAND, SUPPLY AND MARKET} PRICE

Connections

Key concepts

Demand

Supply

The determinants of price

The effects of changes in the underlying conditions of demand and supply

Elasticity of demand and supply

Review questions

\section{THE PRICE MECHANISM AND MARKET FAILURE}

Connections

Key concepts

The functions of price

The rationing function

The 'signalling' function
An optimum allocation of resources $\quad 38$

Market failure $\quad 38$

Disadvantages of the price mechanism 41

Review questions

\section{SOME APPLICATIONS OF PRICE THEORY}

Connections

Key concepts

Price controls

44

Black markets: tickets for a big event $\quad 46$

The price of new houses $\quad 47$

Rent controls 47

Agricultural support policies $\quad 48$

Review questions $\quad 50$

6 THE BASIS OF DEMAND 51

Connections 51

Key concepts $\quad 51$

The law of diminishing marginal utility 51

Indifference analysis $\quad 52$

Normal, inferior, Giffen and Veblen goods $\quad 56$

Review questions $\quad 60$

Appendix 1: The principle of equi-marginal returns

61

Appendix 2: Indifference curves and total utility

Appendix 3: Non-intersection of indifference curves

Appendix 4: The income and substitution effects of a price change

7 THE LAWS OF RETURNS

Connections

Key concepts

The laws of returns $\quad 66$

Economies of scale $\quad 68$

Diseconomies of scale $\quad 69$

The growth of firms $\quad 70$

Survival of small firms $\quad 71$

Review questions $\quad 73$ 


\section{COSTS AND REVENUE}

Connections

Key concepts

Costs in the short run: fixed costs and variable costs

Average (unit) and marginal costs

The behaviour of short run variable costs

The behaviour of average fixed costs and total average cost

The behaviour of average costs in the long run

The long run average cost curve

The firm's revenue

The firm's profit

The break-even level of output

Review questions

\section{THE FINANCE OF INDUSTRY}

Connections

Key concepts

Sources of finance

The gearing ratio

The Stock Exchange

Review questions

10 PERFECT COMPETITION

Connections

Key concepts

Assumptions

Market conditions

Equilibrium of the firm and industry

Efficiency

The supply curve under perfect competition

Review questions

\section{MONOPOLY}

Connections

Key concepts

Sources of monopoly

The theory of monopoly

Some important points regarding the theory of monopoly

Perfect competition versus monopoly

Contestable markets

Government monopoly policy

Monopoly policy in the UK

Review questions

\section{PRICE DISCRIMINATION}

Connections

Key concepts

Conditions under which price discrimination can take place

First degree price discrimination
Second degree price discrimination

Third degree price discrimination $\quad 104$

Disadvantages of price discrimination $\quad 105$

Advantages of price discrimination $\quad 105$

Review questions 108

13 IMPERFECT COMPETITION

109

Connections

109

Key concepts

109

Monopolistic competition $\quad 109$

Oligopoly

111

Review questions

14 LABOUR

118

Connections

118

Key concepts

118

118

120

122

127

128

15 ENTERPRISE

$\begin{array}{ll}\text { Connections } & 128 \\ \text { Key concepts } & 128\end{array}$

What is an entrepreneur? $\quad 128$

Entrepreneurship in large firms $\quad 129$

Implications for the theory of the firm $\quad 130$

Review questions

136

16 LAND AND CAPITAL $\quad 137$

Connections 137

Key concepts 137

Land 137

Capital 138

Review questions $\quad 141$

\section{THE DISTRIBUTION OF FACTOR} INCOMES

142

Connections 142

Key concepts $\quad 142$

Wages 142

Economic rent 149

Profit 150

Interest 151

The personal distribution of incomem and wealth 151

The functional distribution of income 152

Review questions 155

\section{NATIONAL INCOME AND ITS} MEASUREMENT

Connections

Key concepts 
The problems of measurement

Defining national income

Measuring national income

Exclusions from national income

Nominal income and real income

Personal income and personal disposable income

Measuring economic welfare

International comparisons of the standard of living

Uses of national income statistics

Review questions

\section{THE DETERMINATION OF NATIONAL INCOME}

Connections

Key concepts

The model of income determination

Review questions

\section{NATIONAL INCOME DETERMINATION: THE FOUR- SECTOR ECONOMY}

181

Connections

Key concepts

Income determination in a three-sector model: the government sector and aggregate demand

The equilibrium level of national income in a three-sector model

The three-sector multiplier

The three-sector model: the injections and leakages approach to income determination

The balanced budget multiplier

Income determination in a four-sector model: the foreign trade sector and aggregate demand

An increase in export expenditure

The four-sector multiplier

Review questions

\section{INVESTMENT}

Connections

Key concepts
A change in government exenditure

\section{AGGREGATE DEMAND AND} AGGREGATE SUPPLY

Connections 197

Key concepts 197

The aggregate demand curve $\quad 197$

Aggregate supply 198

Long run equilibrium 199

Factors causing a change in aggregate demand 200

Factors causing a change in aggregate supply 202

The effect of a change in aggregate demand 203

The effect of a change in aggregate supply 205

Review questions

\section{MONEY AND THE CREATION OF BANK DEPOSITS}

Connections

Key concepts 208

The functions of money 208

Components of the money supply 209

The creation of bank deposits 210

The multiple expansion of bank deposits $\quad 210$

Review questions 213

24 THE MONETARY SECTOR $\mathbf{2 1 4}$

Connections 214

Key concepts 214

The securities traded in the money market 214

Financial intermediaries $\quad 217$

The Bank of England 217

The discount market $\quad 219$

The retail banks 220

Accepting houses 222

The parallel money markets $\quad 222$

The Euro-currency market 223

Review questions 224

25 MONETARY CONTROL 225

Connections 225

Key concepts 225

Defining the money supply 225

The background to monetary policy 226

Techniques of monetary policy 229

Review questions 231

26 INTEREST RATES 232

Connections 232

Key concepts 232

What is 'the rate of interest'? 232

Why are there so many rates of interest? 233

The loanable funds theory 233 
A modern approach to loanable funds theory

Liquidity preference theory

The term structure of interest rates

The nominal rate of interest and the real rate of interest

Review questions

27 MEASURING CHANGES IN THE VALUE OF MONEY

Connections

Key concepts

Price relatives

Index numbers

247

247

248

248

250

251

251

254

Review questions

\section{INFLATION}

Connections

Key concepts

The quantity theory of money

The Keynesian view of inflation

The inflationary sprial

The Phillips Curve

The consequences of inflation

Review questions

\section{RATIONAL EXPECTATIONS IN ECONOMICS}

Connections

Key concepts

The importance of expectations

Adaptive expectations

Rational expectations

Rational expectations and policy-ineffectiveness

The policy implications of rational expectations

Criticisms of the rational expectations hypothesis

Assessment of rational expectations

Review questions

\section{INTERNATIONAL TRADE}

Connections

Key concepts

Theories of international trade

Criticisms of the principles of absolute and comparative advantage

Intra-industry specialisation

Review questions

268
31 FREE TRADE AND PROTECTION

Connections

Key concepts

290

Types of restriction on trade $\quad 290$

Arguments for protection 292

Arguments against protection $\quad 294$

The 'New Protectionism' 297

The General Agreement on Tariffs and Trade 297

Review questions

301

\section{THE BALANCE OF PAYMENTS}

302

Connections

Key concepts

302

302

The causes of the UK's balance of payments deficit

305

Review questions

308

\section{EXCHANGE RATE SYSTEMS}

Connections

Key concepts

The foreign exchange market

The determination of exchange rates in free markets

Factors causing movements in free market exchange rates

Fixed exchange rates

Advantages of floating exchange rates $\quad 316$

Disadvantages of floating exchange rates $\quad 317$

Advantages of fixed exchange rates $\quad 318$

Disadvantages of fixed rates $\quad 318$

The effective exchange rate $\quad 319$

Depreciation and the current balance $\quad 319$

Attributes of an effective monetary system $\quad 320$

The International Monetary Fund 321

Components of international liquidity 321

Review questions 323

\section{EUROPE'S ECONOMIC COMMUNITY 324}

Connections $\quad 324$

Key concepts $\quad 324$

Types of economic integration 324

Institutions of the EC 324

Financing the EC 325

Why is there an EC? 325

EC policies 327

1992: the removal of barriers to trade 331

1992 and European monetary union 332

The UK 'hard ecu' proposal 333

1992 and EC competition policy 333

Review questions 335 
35 PUBLIC FINANCE AND TAXATION 336

Connections

Key concepts

Why do governments spend?

Why do governments levy taxes?

The Budget

The National Debt

Classification of taxes

The principles of taxation

Income tax in the UK

Some less well-known taxes

The impact and incidence of indirect taxes

Direct taxes versus indirect taxes

Review questions

36 STABILISATION POLICY

Connections

Key concepts

The objectives of stabilisation policy

Demand management techniques

Conflict between policies?

Why do policies conflict?

Review questions

344

353

353

353

353

355

357

358
37 SUPPLY-SIDE POLICIES IN THE UK $\mathbf{3 5 9}$

Connections $\quad 359$

Key concepts $\quad 359$

The advent of 'supply-side' economics $\quad 359$

Reforming the labour market $\quad 359$

Tax reform 363

Deregulation 366

Privatisation 366

Supply-side policies: have they worked? 369

UK competitiveness in the 1980s 371

Review questions 372

345

352

358

\section{DEVELOPMENT AND THE PROBLEMS OF THE LESS DEVELOPED COUNTRIES}

Connections

$\begin{array}{ll}\text { Glossary } & 387 \\ \text { Index } & 393\end{array}$ 
1.1 A typical production possibility curve

2.1 UK visible imports by commodity; and UK volume of imports

2.2 UK volume of imports, 1980 and 1989

2.3 A supply curve

2.4 A demand curve

2.5 'Steady decline in savings'

2.6 'Savings collapse'

2.7 Using a moving average to smooth data

2.8 Revisions of UK unemployment data

3.1 Movements along a demand curve

3.2 Shifts of a demand curve

3.3 Movements along a supply curve

3.4 Shifts of a supply curve

3.5 The determination of equilibrium price

3.6 Altering the underlying conditions of supply and demand: graphical presentation

3.7 Altering the underlying conditions of supply and demand: tabular presentation

3.8 Elasticity of demand when price rises from $£ 2$ to $£ 4$

3.9 Demand curves with constant elasticity

3.10 Price changes and total revenue

3.11 (Price) elasticity of supply

3.12 Elasticity of supply in the momentary period, the short run, and the long run

4.1 The market working perfectly

4.2 The 'polluter pays' principle

4.3 Social cost

4.4 Supply and demand conditions for car parking in a busy town centre

5.1 Maximum and minimum price controls

5.2 Inelastic supply and demand determined price

5.3 The supply of and demand for new houses

5.4 Shortage of rented property and rent increases
5.5 The operation of an agricultural support scheme

49

5.6 Horizontal world supply curve 50

6.1 An indifference curve 53

6.2 An indifference map 53

6.3 A budget line 54

6.4 Changes in the budget line 54

6.5 Consumer's maximum possible level of utility

6.6 Indifference map for a normal good 55

6.7 Normal and inferior goods 55

6.8 The indifference curve and the downward sloping demand curve $\quad 56$

6.9 Types of good $\quad 57$

6.10 Matrix box 60

6.11 Equi-marginal returns 61

6.12 Indifference curves and total utility 63

6.13 Non-intersection of indifference curves 64

6.14 The demand curve, the cross demand curve, and the Engel curve

7.1 Marginal and average product of labour

7.2 The implications of integration

8.1 Short run relationship between costs and returns

65

67

70

76

8.2 Graphical presentation of unit and marginal costs

8.3 Short run average cost curves

8.4 Short run cost structures in the steel industry

8.5 Long run average cost curve

8.6 Break-even circulation

10.1 Relationship between the market and the firm in prefect competition

10.2 Equilibrium of the firm: firms entering the industry

10.3 Equilibrium of the firm: firms leaving the industry

Marginal cost and the supply curve

10.5 Supply in the long run The equilibrium of a mono

11.2 Monopoly price and quantity

5

.

57

60

3

64

5

76

77


12.1 Perfect price discrimination

12.2 Second degree price discrimination

12.3 Third degree price discrimination

12.4 Profits and losses without and with discrimination

13.1 Short run equilibrium under monopolistic competition

13.2 Long run equilibrium under monopolistic competition

13.3 The oligopolist's 'kinked' demand curve

13.4 The oligopolist's absorption of a rise in costs

13.5 The oligopolist's reaction to changes in demand

14.1 Population change and its components, England and Wales, 1971-2 to $1987-8$

14.2 UK density of population per square mile

14.3 UK proportion of males and females, by age group

14.4 Percentage of UK workforce in primary, secondary and tertiary industry, 1987

14.5 Optimum population

14.6 Age structure of UK, 1891 and 1988 and of EC, 1990 and projected 2020

15.1 Types of business organisation, private sector, UK

15.2 Brand names and trade marks owned by Hillsdown Group plc

15.3 What motivates tycoons

16.1 Rises in land prices, UK, 1987-8

16.2 Production possibility curve for consumer and capital goods

17.1 The profit maximising number of workers employed

17.2 The equilibrium wage rate in an occupation

17.3 Changes in the wage rate

17.4 Elasticity of supply of labour and wages

17.5 The effect of a monopsonist on the wage rate

17.6 Transfer earnings and economic rent

17.7 Transfer earnings and economic rent

17.8 Distribution of personal income, UK, 1989

17.9 Distribution of marketable wealth, UK, 1987

17.10 Functional distribution of income, UK, 1960 and 1987
103

104

105

106

110

111

112
17.11 Membership of TUC-affiliated trade unions, 1970-90

154

17.12 A Lorenz Curve 154

17.13 Lorenz curves of income earned and earners

18.1 Value added at each stage of production

18.2 Shares in GDP, main industrialised countries, 1985

18.3 GDP per head, main industrialised countries, 1985

19.1 Consumption, investment and aggregate demand

19.2 The equilibrium level of income in a two-sector economy

19.3 Savings, investment and equilibrium

19.4 An increase in aggregate demand

19.5 The effect of a reduction in aggregate demand

19.6 A reduction in planned savings $\quad 177$

20.1 An increase in aggregate demand in the three-sector model

20.2 The equilibrium level of income: planned injections equals planned leakages

20.3 The equilibrium level of income in a four-sector economy

20.4 The effect of an increase in exports

21.1 The equilibrium level of investment 193

22.1 A typical aggregate demand curve

22.2 Aggregate supply in the short run and the long run

22.3 Short and long run equilibrium between aggregate demand and aggregate supply

22.4 A change in aggregate demand

22.5 A change in aggregate supply in the short run and the long run

22.6 The effect of an unanticipated increase in aggregate demand on price and output in the short and in the long run

22.7 The effect of an unanticipated reduction in aggregate demand

22.8 The effect of a supply shock on output and prices in the short and long run

22.9 The effect of an increase in wages on prices and output in the short and long run

22.10 The effect of an increase in investment on prices and output in the short and long run

23.1 Deposit of $£ 100,000$ in Bank A's balance sheet 
23.2 Withdrawal of $£ 90,000$ from Bank A's balance sheet

23.3 Transfer of funds from Bank $A$ to Bank $B$ : Bank $B$ 's balance sheet

23.4 Fall in Bank $B$ 's cash reserves after a loan

23.5 Multiple increase in total bank deposits

24.1 A Treasury bill

24.2 A local authority bond

24.3 The financial system

25.1 Relationships between the monetary aggregates and their components

26.1 Supply and demand for loanable funds 234

26.2a The effect of a change in the demand for loanable funds on the rate of interest

$26.2 \mathrm{~b}$ The effect of a change in the supply of loanable funds on the rate of interest

26.3 The transactions demand for cash and the level of income

26.4 The effect of a change in the frequency of income receipts on an individual's average transactions demand for money

26.5 Speculative or asset demand for money

26.6 Overall demand for money in the liquidity preference theory

26.7 The equilibrium rate of interest

26.8 Supply and demand for money in equilibrium

26.9 The effect of changes in the demand for money on the position of the liquidity preference curve

26.10 The effect of an increase in the demand for money is offset by an accommodating increase in the supply of money

26.11 A normal yield curve

26.12 The effect on the yield curve of an expected fall in interest rates

28.1 The effect of an increase in aggregate demand on the price level

28.2 The effect of an increase in costs on the price level

28.3 The inflationary spiral

28.4 The Phillips Curve

28.5

Employment and the real wage

28.6 Short run Phillips Curves and the expectations augmented or long run Phillips Curve
28.7 Inflation and unemployment, UK, 1976-90

28.8 A short run Phillips Curve for the UK, 1986-90

29.1 The effect of an unanticipated increase in the money supply of $x$ per cent

29.2 The effect of a perfectly anticipated increase in the money supply of $x$ per cent

29.3 An anticipated increase in the money supply: the price level and real output 272

29.4 Interest rates and growth of money supply, UK, 1980-89

30.1 A production possibility curve and a trading possibility curve

30.2 Units of labour required per $\$ \mathrm{~m}$ of output: intercountry comparison, 1980286

31.1 The effect of a tariff on economic welfare

32.1 The behaviour of the UK Current Account

32.2 UK motor industry trade deficit cut

33.1 Equilibrium rate of exchange 313

33.2 Inflation and the sterling/dollar exchange rate

314

33.3 Maintaining the fixed exchange rate 316

33.4 The J Curve effect 320

33.5 Supply and demand for sterling 323

34.1 Supply and demand analysis of the CAP arrangements

35.1 Vertical equity

35.2 Personal allowances and income tax rates, UK, 1989/90

35.3 Tax/benefit changes and the poverty and unemployment traps

35.4 Impact and incidence of taxation 344

35.5 Choices between income and leisure 351

36.1a The deflationary gap 355

$36.1 \mathrm{~b}$ The inflationary gap 355

36.2 The Neo-Keynesian 'box' 356

36.3 The effects of direct policies on aggregate demand

357

37.1 The unemployment trap 365

37.2 Indicators of competitiveness, UK, 1970s and 1980s

38.1 Investment as a percentage of GNP

378

38.2 Past and projected world population

384

38.3 Age structure in the UK, and India, 1985 


\section{LIST OF TABLES}

2.1 UK visible imports by commodity, 1980 and 1989

2.2 Price and quantity supplied

2.3 Price and quantity demanded

2.4 Increase in personal income on previous year

2.5 Expenditure on motor vehicles: moving average

2.6 Expenditure on motor vehicles: seasonally adjusted data

2.7 Average weekly earnings of manual workers, UK manufacturing industry, 1988

3.1 Income and own-price elasticities of demand and cross elasticities of demand

3.2 Estimate own-price, cross and income elasticities

6.1 Combinations of apples and pears giving equal levels of utility

7.1 Output change as more workers are employed

7.2 UK firms, employment and turnover, 1986 and 1979

7.3 Output variation with increasing amounts of labour and fixed amounts of other factors

8.1 The behaviour of variable and marginal cost

8.2 Behaviour of average total cost

8.3 Behaviour of average revenue and marginal revenue as sales change

8.4 Relationship between revenues, costs and profit at various levels of output

9.1 Sources of funding for UK industrial and commercial companies

11.1 Market conditions and monopoly

11.2 Main instruments of UK monopoly

13.1 Concentration ratios in selected industries

14.1 Internal migration

17.1 Physical product and revenue product

17.2 The effect of state intervention on the distribution of personal income
17.3 Male and female earnings and employment

18.1 National income, UK, 1989

18.2 PPPs and exchange rates, $1985 \quad 167$

18.3 GDP, 1985, £bn 168

18.4 GDP, 1985, £per head 168

19.1 Aggregate demand in a two-sector economy

172

19.2 The equilibrium level of national income

172

19.3 Planned investment exactly equals planned savings

19.4 MPC, proportion of extra income spent on consumption, and the muliplier effect

19.5 Planned investment, national income and savings

19.6 A reduction in aggregate demand 177

19.7 Disposable income, consumption and savings, 1983-90

19.8 Household wealth, 1984-8 180

21.1 Discounting to present value $\quad 190$

21.2 The mechanics of the accelerator 192

21.3 Investment and GNP, 1978-88 196

24.1 Banks in the UK: combined balance sheet of monthly reporting institutions 221

27.1 Index of prices

27.2 Weighted index of prices 249

27.3 Weights assigned to items in the RPI 250

27.4 Changes in prices and the value of money

28.1 Inflation in the Weimar Republic, 1913-23

28.2 Inflation in Hungary, 1938-46

29.1 Changes in GDP, inflation, unemployment and money growth, UK, $1980-5$

30.1 World exports, 1981-9

30.2 Production possibilities for wheat and cars, UK and Portugal

30.3 Units of output produced without specialisation, UK and Portugal

30.4 Units of output produced after specialisation, UK and Portugal 
30.5 Specialisation by absolute advantage 281

30.6 Comparative advantage

30.7 Self-sufficiency and complete specialisation, UK and Portugal

30.8 Partial specialisation

30.9 Growth of exports

30.10 Intra-bloc trade as percentage of total trade

30.11 Successful international specialisation

30.12 Value added per worker and wage rate, developed and developing countries

31.1 Annual average growth of per capita real GNP, 1973-85

31.2 Relative magnitude of welfare effects, USA

32.1 UK balance of payments, 1990

32.2 UK balance of payments deficit, 1986-91

32.3 Interest, profits and dividends, 1988Q1-1989Q4
32.4 Net invisible exports, 1985-90 307

32.5 Increase in domestic demand 307

33.1 Rates of exchange 311

33.2 International reserves 322

$34.1 \quad$ EC revenue and expenditure, $1988 \quad 325$

34.2 CAP financial support, $1988 \quad 328$

34.3 Value of an ecu, $1990 \quad 330$

34.4 Inflation rates before and after EMS 331

35.1 Tax revenues raised, 1990-91 338

37.1 The costs of four UK privatisations 368

37.2 UK privatisations 368

37.3 Growth of labour productivity 369

37.4 International comparison of output per head 370

38.1 Economic development 375

38.2 Economic indicators in two groups of developing countries 377

38.3 The 'Asian Dragons' 378

38.4 Aid to developing countries 379

38.5 IDA aid commitments by region 383 


\section{ACKNOWLEDGEMENTS}

The authors and publishers wish to thank the following for permission to reproduce copyright material:

The Economic Review, for Figure 2.8 (January 1990) and Figure 8.4, from J. Aylen, 'Cost Curves in the Steel Industry' (September 1989), and for Table 3.2, in E. Symons and I. Walker, 'Fiscal Harmonisation' (May 1990) and Table 38.3, from the Data Supplement (1990).

Hillsdown Group plc for Figure 15.2.

Fiscal Studies for Figure 35.3.

Barclays Bank Review for Figure 37.2.

Finance and Development for Figure 38.2 and for Table 38.5.

Philips for Figure 38.3, from Philips Certificate Atlas (1987).

Daily Mirror for the extract on p. 108.

Department of Employment Gazette for Tables 7.2, 17.3 and 27.3 and for Box 27.2.

National Westminster Bank Review for Table 28.2.

Federal Reserve Bank of St Louis Review for Tables 31.1, 31.2 and for material in Box 31.3.

Barclays Country Report for Question 1 on p. 288 and Question 5 on p. 309.

Barclays Economic Review for Tables 32.2 and 32.5. Lloyds Bank Economic Bulletin for Table 34.3.

Lloyds Bank Economic Profile for Figure 2.1.

Economics (Journal of the Economics Association) for Tables 37.3 and 37.4 and for Figure 37.1.

The Economist for Tables 30.5 and 38.2, for Figure 38.1 and for material in Box 38.5.

BIS Financial Review for Table 34.4, from N. Healey

'The Great EMS Debate 1990 Vintage (May 1990).

The Bank of England for Figures 24.2, 25.1 and 29.4 and Table 24.1.
Bank of England Quarterly Bulletin for Table 30.10. The Financial Times for Table 33.1.

The IMF for Tables 30.9, 33.2, 38.4, for Figure 30.2 and for material in Boxes 31.1, 31.2, 31.4, 38.2.

The Controller of Her Majesty's Stationery Office for Figures 2.2, 2.5, 2.6, 2.7 14.1, 14.2, 14.3, 14.4, 14.5, 17.7, 17.8, 17.9, 17.10, 28.7, 32.1 and for Tables 2.1, 2.4, 2.6, 2.7, 3.1, 3.2, 14.1, 17.2, 18.1, 19.7, 19.8, 21.3, $29.1,32.1,32.3,32.4,35.1,37.2$ and for material included in Boxes 13.1 and 35.1.

Nottingham City Council for Figure 24.2.

The EC for Tables 34.1 and 34.2.

The IDA for Figure 38.5 .

The Independent for material in Boxes 37.1 and 37.2.

The IBRD for Figures 38.1 and 38.2 and for material in Boxes 37.3, 38.1, 38.3 and 38.4.

The IEA for Table 37.1.

The OECD for Tables 18.2, 18.3, 18.4 and for Figures 18.2 and 18.3 .

The Guardian for Figures 14.6, 15.3, 32.2, 33.2 and for material in Boxes 14.1 and 37.5.

The Sunday Times for Figure 16.1 .

The Observer for material in Box 16.1.

GATT for Table 30.1.

Macmillan Publishers for material in Box 30.4 and for Table 30.11 from M. Porter, The Competitive Advantage of Nations.

UNIDO for Figure 30.2, for Table 30.12 and for material in Box 38.2.

The UN for Table 38.4 and for material in Boxes 31.1, 31.2 and 31.4.

Every effort has been made to trace all the copyright-holders, but if any have been inadvertently overlooked the publishers will be pleased to make the necessary arrangement at the first opportunity. 
This book is designed to provide a modern and thorough treatment of introductory economics. Although written primarily with the needs of the ' $\mathrm{A}$ ' level student in mind, it will also be useful to those taking non-specialist courses in economics in universities and polytechnics, as well as those studying for professional qualifications.

The emphasis throughout the book is on clarity, accuracy and relevance. It is hoped that this will stimulate interest and encourage understanding. We have sought to explain the most complex aspects of the subject in a way that is sympathetic to the needs of students at this level, many of whom have no prior knowledge of economics. We have also sought to show the relevance of what can often appear to be abstract theory by providing real-world examples wherever possible to illustrate the importance of theory in understanding the economic environment.

Economic terminology is used throughout the book to enhance understanding of the subject and to enable readers to follow the coverage of economic events in the media. However, we hope readers will find the book free of jargon and we make no apologies for its absence.

There are several features of this book, apart from clarity and accuracy, which we feel will appeal to readers. Each chapter begins with a section entitled Connections, which relates the material to be covered in that chapter to other topics covered in the book. This is particularly important in a subject like economics where material covered in one chapter is often related to material covered in other chapters. This is followed by a list of Key Concepts that are introduced and discussed in the chapter. There are also Review Questions at the end of each chapter which are designed to provide a check on progress and understanding. Most chapters also contain case study or insight material which is set in boxes so as not to interrupt the flow of the text. The boxes often given an application of economic theory or provide an illuminating insight into material covered in the chapter.

We are aware that not all students taking courses in economics have a strong mathematical background and we have therefore devoted a complete chapter to explaining and interpreting typical graphs and charts that are widely used in teaching introductory economics. There is also an explanation of time-series data and we hope this chapter will give confidence to readers who lack a strong mathematical background. More generally we hope it will be useful in preparing all candidates for the data response paper that all major examination boards now set.

The book is also modern in its approach. Recent developments in theory are treated thoroughly and there are separate chapters on the aggregate demand/aggregate supply framework now used in analysing economic policy and on rational expectations. There are also separate chapters on monetary policy, the Economic Community and economic development which provide a careful and detailed analysis of these areas where change has been rapid in recent years.

We are grateful to many people for their help, support and encouragement during the writing of this book. We would like to thank the entire team at Macmillan for their help and encouragement and must place on record our particular thanks to Stephen Rutt. We would also like to thank Stan Goodman of Rickmansworth School, Hertfordshire, John Wigley of Haberdashers' Aske's School, Elstree, and Phyllis Palmer of Dinnington Comprehensive School, Sheffield, for valuable comments on earlier drafts of this book. They are responsible for many improvements to the text, but as we have not always accepted their advice we are unable to implicate them in any errors or omissions that remain. We are also grateful to Keith Povey and his editorial team (Barbara Docherty, Ann Edmondson and Tony Edmondson) for their efforts in ensuring the book's smooth passage to the printer. Finally, we would like to thank our wives and families for all the support and encouragement they have given us during the writing of this book. 